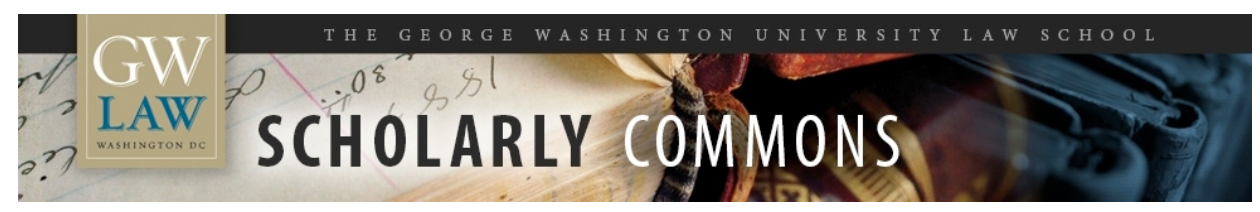

\title{
Adjudication, Antisubordination, and the Jazz Connection
}

Christopher A. Bracey

George Washington University Law School, cbracey@law.gwu.edu

Follow this and additional works at: https://scholarship.law.gwu.edu/faculty_publications

Part of the Law Commons

\section{Recommended Citation}

Alabama Law Review, Vol. 54, 2003

This Article is brought to you for free and open access by the Faculty Scholarship at Scholarly Commons. It has been accepted for inclusion in GW Law Faculty Publications \& Other Works by an authorized administrator of Scholarly Commons. For more information, please contact spagel@law.gwu.edu. 


\title{
AduddicAtion, AnTisubordination, And THE JAZZ CONNECTION
}

\author{
Christopher A. Bracey ${ }^{*}$
}

\section{INTRODUCIION}

We live in the midst of a pervasive and sustained democratic crisis. Our society expresses a deep commitment to core notions of freedom, justice, and equality for all citizens. Yet, it is equally clear that our democracy tolerates a great deal of social and economic inequality. Membership in a socially disfavored group' can (and often does) profoundly distort one's life chances and opportunities. Group conflict and competition for social status is native to the human condition and to democratic life. Our constitutional democracy acknowledges this tension, providing for both majority rule and the protection of minority rights and interests. The protection of minority rights and interests takes the form of express prohibitions on the subordination of certain social groups. ${ }^{2}$ Nevertheless, our society retains informal structures and networks that have the effect of perpetuating social inequality among groups-social inequality that was once secured by formal law. ${ }^{3}$ As Alexis de Tocqueville prudently observed,

* Associate Professor of Law. Washington University School of L.aw. I woukl like to thank Barabara Flagg, F. Scon Kieff, Paulime Kim, Troy Paredes. Laura Rosenbury, and my research assistant Lise Byars for their comments and thoughtful contrihutions.

1. Socially disfavored groups include those that are readily identifiable, such as racial and ethnic minorities, women, and persons sulfering from obvious disabilities. However, certain groups, sueh as gays, lesbians, religious minorities, and persons suftering from more subtle disabilities, might also hear the hrunt of social disfivor, though their distinctiveness is less readily identifiable. See, $e . g$. , Kenji Yoshimo, Covering, 111 YALE L. J. 769 (2002) (discussing harm experienced by members of the gay and leshian community as a result of having to mask their sexual orientation in order to avoid social dislavor).

2. The Reconstruction Amendments and the Civil Rights Act of 1964 are the most prominent examples of express prohibitions on the subordination of members of socially disfavored groups. The Equal Protection Clatse of the Fourtecnuls Amendment prohibits state oflicials from engaging in actions that discriminate against any citizen or group ol citizens. U.S. Const. amend. XIV. Similarly, the Civil Rights Act prohibits private parties from discriminating against others with regard to employment, public accommodations, and education on the basis of race, color, religion, sex, or national origin. 42 U.S.C. $\$ 2000$ e-2 (2000). Together, these legal provisions emboly a tundamental moral principle that probibits the subordination of sociatly distavored groups.

3. Chattel slavery, of course, is the most egregious example. Compare U.S. Const. pmbl, whih U.S. CONST, art, I, \$ 2. cl. 3 (comting slaves as three-filths of one person for political representation purposes), U.S. CoNst. art. I, $\$ 9, \mathrm{cl}, 1$ (allowing for the importation and federal taxing of slave labor until the 1808), U.S. CONST. art. IV, s 2, cl. 3 (creating a constitutional right to the relum of 
"IT|he real inequality that is produced by fortune or by law is always succeeded by an imaginary inequality that is implanted in the manners of people." ${ }^{4}$ Confronted with entrenched and destructive patterns of social and economic stratification, what more can law do to realize democracy for members of subordinated groups?

In this Article, I offer some preliminary thoughts on how law should respond, and in particular, what we might ask of judges and the Constitution that they interpret and uphold. It seems, at first blush, a bit cliché, if not naive, to look to the judiciary in the current climate for assistance in the struggle to realize democracy for members of socially disfavored groups. ${ }^{5}$ Yet it strikes me that judges play a critical role in shaping our democracy, especially in civil rights cases where, as often occurs, courts are called upon to mediate conflicts between majority rule and minority rights. Equal Protection and Due Process cases go to the heart of our democracy, and adjudication of such cases is a task of central democratic importance because it is through the medium of these cases that judges interpret the Constitution to give content and meaning to our civil rights. Adjudication in this context, as in any other context, requires judges to mediate tensions between principle and practice, the abstract and the concrete, the general and the specific, and the like. Yet, one can (and perhaps should) understand the adjudication of civil rights cases as both an expres-

lugitive slaves), and U.S. CONST. art. 5 (prolibiting amendment of the slave importation and taxation provision of the Constitution prior to 1808). For other examples of subordination of social groups sanctioned by law, see The Indian Removal Act of 1830, 25 U.S.C. \$ 174 (2000) (outlining the United Slates policy for forcible relocation of Native Americans); The Uniform Naturalization Act of 1790 , ch. 3, I Stat. 103 (1790) (repealed 1795) (restricting naturalization to "liee white person[s|"): and 'The Chinese Exclusion Act of 1882, ch. 126. 22 Stat. 58 (1882) (repealed 1943) (harring entry of Chinese laborers into the United States for ten years).

4. ALI:XIS DE TOCQUI:VILLI:, DI:MOCRACY IN AMFRKA 357 (Phillips Bradley ed., 1945).

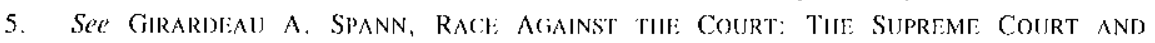
MINORITIIS IN CONTIMPORARY AMFRICA 3 (1993) ("The inevilability of Supreme Court review is likely to have an adverse effect on minority incerests because the Supreme Court has been structured to operate in a manner that is inherently conservative. TThe Court's inherent conservatism impairs minority efforts to achieve racial equality."). Others press the argument further, suggesting that law itself may be incapable of responding meaningfully to subordination. See Richard Delgado \& Jean Stefancic, The Social Constraction of Brown v. Board of Education. Law Reform and the Reconstructive Paradox, 36 WM. \& MARY L. REV. 547, 568 (1995) ("IR felomers should hesilate lo place much laith in the legal system as the primary instrument for their agendas. Law is relatively powerless to effect social revolutions as both theory and history . . . temonstrate.").

6. See edward A. Purceil, JR., The Crisis of Democratic Theory: SCIFntefic Naturalism \& THE Probllim OF VAluJ: (1973) (oflering a general account of legal intellectual concern that the treatment of Alrican-Americans. expecially in the South, diel not live up to elemocratic ideals); William N. Eskridge, Jr., Some Effects of ldemity-Based Social Movements on Constintional Law in the Twenteth Century, 100 Miclı. L. Rr:V. 2062, 2377 (2002) (observing that "ibly 1938, the New Deal Justices were aware that people of color were politically excluded and denied lundamental rights in the South and believed that this state of affairs was fundamentally inconsistent with the principles of democracy that the United States claimed to represent in opposition to Nazi and Communist (otalitarianism"). 
sion of the current state of society and a window into our democratic future.

This is not to suggest that transformations in formal law and adjudication in particular are the end-all and be-all of a constitutional democracy. As Professor Jack Balkin writes, "[T]he democratic ideal calls for a social revolution ... [which] cannot be achieved through legal regulation alone . .. ." By this Balkin means that true democracy cannot exist without the presence of a "democratic culture" that works to eliminate "all the devices of social stratification, even those that persist in the face of legal reform." Balkin is undoubtedly correct in that the fullness of democracy is contingent upon the social or cultural commitment of the people to the democratic enterprise. All democratic communities take form against the backdrop of a preexisting society, and as James Baldwin eloquently explains:

[I]t is exceedingly difficult for most of us to discard the assumptions of the society in which we were born, in which we live, to which we owe our identities; . . . virtually impossible, if not completely impossible, to envision the future, except in those terms which we think we already know."

Yet there is something distinctive about American democracy, and its reliance upon law to generate and maintain social order. Professor Lawrence Friedman eloquently captures this unique role of law in American democracy when he writes: "II]n complex societies custom is far too flabby to do all the work - to run the machinery of order. Law carries a powerful stick: the threat of force. This is the fist inside its velvet glove." "Must we wait for Balkin's "social revolution" in order to realize democracy for subordinated groups, or is there more that we can presently ask of law? In particular, can we ask more of judges or the Constitution

7. Indeed, a mumber of scholars now argue that so-called landmark Supreme Court decisions, such as Brown v. Board of Educotion, affect litle, il any, real change on their own. See Gi:RAI.D N Rosenberg;, Thi: Hollow hope: Can Courts Bring about' Social. Changie? I57 (1991) (concluding that there is "little evidence that the judicial system, from the Supreme Court down. produced mucl of the massive change in civil rights that swept the United States in the 1960s"); Michael J. Klarman. Brown, Racial Change, and the Civil Rights Movement, 80 VA. L. REv. 7, 10, 13 (1994) (using empirical evidence to support an argument that littc changed in the South immediately postBrown and noting that Brown's short-term effects were "indirect" and "almost perverse"): Stuart Scheingold, Constitutional Rights and Social Change: Civil Rights in Perspective, in Jubring; thl:

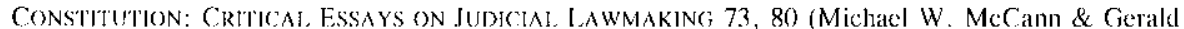
L. Houseman eds., 1989) ("IClourts have sufficient power to politicize-lo provoke a crisis-but not to effect social change on their own.").

8. J.M. Balkin, The Constitution of Status, 106 YAl, L. J. 2313, 2314 (1997).

9. $\quad l d$.

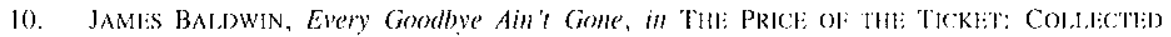
NONI:TCTION 1948-1985, at 643 (1985) (emplasis added).

II. LAWRENCI: M. FRIEDMAN, AMERICAN IAW 257 (1984). 
they interpret and uphold? If so, what would this style of adjudication look like?

This Article is an effort to develop an attractive normative and descriptive account of "successful" judging in constitutional civil rights cases in a democratic society. By "successful," I mean to describe a style of judging that is self-consciously engaged in the constructive enterprise of giving full meaning and content to minority rights in a manner consistent with the best of the American democratic tradition of freedom and majority rule. Successful judging, in this context, is judging that offers maximum protection of minority interests without running afoul, so to speak, of political theory. In short, successful judging is judging deliberately styled to realize democracy for subordinated groups in American society.

The portrait of successful judging I offer here is inspired, to a large extent, by what is often referred to as "free jazz." A number of musicians and academics have used jazz music as a metaphor for the proper balance of rights and responsibilities within democratic society. ${ }^{12}$ The jazz metaphor works on a number of levels. The jazz ensemble is a pluralistic association of different "voices." Like a pluralistic society, the jazz ensemble requires an acknowledgment and appreciation of rich possibilities presented by those voices. Successful jazz is also premised upon a shared sense of community. The successful jazz ensemble must have the will to work and play together as part of the collective enterprise. Jazz, as music,

12. A number of prominemt examples include: CHARI,ES HENRY, CuITURI: ANI) AIRICAN AMTRICAN POIITICS 32 (1990) (describing the significance of jazz in terms of its collectivity); LF:ROI JONES, BLACK MUSIC 13 (1969) (describing jazz music in terms of democratic expression); J.A. Rogitrs, Jazz a Home, in THE NEW NFriko 223-24 (1992) (describing jaz as "mocking disregard lor formality" that "makes for democracy" and embodying a spirit that can "truly democratize"); Lani Guinier, Mone Democracy, 1995 U. C.H. L.s:GAl. I. I (1995) (noting that modern electoral dentocracy is descriptively like a classic American spectator sport, baschall, but should strive to be more like jaze. music): Wyuton Marsalis, A Masterpiece by Midnight. in K!:N BURNS JAZZ (Florentine Fijms 2000) (episode 10) (descrihing the style of production ol jaz music as "exactly like democracy").

This is not to suggest that jazz is the only musical form that might funcrion as a metaphor for democracy. For instance, one might view the symphony orchestra and its emphasis on collectivity and cooperation as a similarly apt metaphor for democtacy. See Adeno Addis, Adjudication and Instinttional leginimacy, 71 B.U. L. REV. 161, 165-66 (1991) (book review) ("ID|emocracy, like an orchestra playing a symphony, involves collective action. Its sucess, just like the success of an orchestra, depends not just on every constituent member acting and playing, but acting in a way that will contribute to the enterprise of the group. It is not the statistical sum of loc action of the constituent parts that defines democracy, but rather how those various acts are linked and how they comtribute to the commumal cnterprisc."); see also Aharon Barak. The Role of a Supreme Coum in a Democracy, 53 HASTINGS L...3. 1205, 1213 (2002) ("Judicial lawmaking is not the only form of lawmaking or even the primary form. The other hramehes also create law. Judicial lawmaking should mesh with this overall lawmaking. The judge is not the only musician within the grand legal orehestra, and his playing musi be in harmony with the rest of the music."); Gregory Basslam, Freedom's Politics: A Review Essay of Ronald Dworkin's Freedom's Law: The Moral Reading of the American Constitution, 72 NOTRE: DAMl: L. REV. 1235, 126I (1997) (book review) ("Wlien we say, for example, that an orchesira or a football team played well, we're saying something about the group as a whole that cannot be adequately reduced 10 a statistical readout of individual performances. Likewise, in a genuine democracy. Dworkin argues, "political decisions are laken by a distines entily-the people as such-rather than by any set of individuals one by one." ). 
is a democratic outcome insofar as it represents a collective expression of the will and ideas of the ensemble through "public conversation." Finally, the value and aspiration of jazz extends beyond the mere production of sound. Beneath the creative process and technical mastery is the belief in a shared principle of humanity. Going through the motions of sound production without sincere engagement in the substance of the jazz enterprise may produce music, but that music will not be jazz.

The free jazz movement of the late 1950s and early 1960 s strikes me as particularly apt when mediating on adjudication in the civil rights context because free jazz was understood as deeply oppositional to more traditional forms of jazz. Much like the judges who confronted the "countermajoritarian difficulty" in their attempts to reconcile liberal judicial activism with political theory, free jazz pioneers faced criticism, opposition, and outright hostility from jazz traditionalists. The free jazz movement literally questioned everything that had happened in jazz up to that point. The movement offered a radically new vision of jazz-a vision that was revolutionary in form and approach, but deeply respectful of traditional concepts of freedom, creativity, and humanity that underlie all musical forms including traditional forms of jazz. The free jazz metaphor is useful, then, in thinking about how judges in the civil rights context might respond to allegations of "liberal activism" or attempts to undermine the legitimacy of a decision that protects minority rights at the expense of majority rule. ${ }^{13}$

I do not contend that the image of adjudication I present here-of what success judges do and ought to do-is the only model for successful judging in this context. Nor is my discussion intended to suggest a list of character attributes or qualities of an idealized constitutional law decision maker. Over the years, a number of scholars have attempted to provide practical lessons and insights to shape judging in a manner that ameliorates tensions created by the countermajoritarian difficulty. ${ }^{14}$ It is in the spirit of

\footnotetext{
13. The jazz metaphor for adjudication, though useful, is not perfect. For instance, one might make profilable comparisons between jazz musicians and individual judges, the jazz ensemble and the judiciary, the jazz music and the democratic outcones of adjudication. But whereas adjudication is for the henefit of the parties (and as I argue leere, for larger society as well), lax production of jazt might be construed as a lundamentally selfish or closed enterprise-that is, musicians make jaz for their own pleasure as much as they do for public consumption. While it is undoubledly true that the prodaction of jaz., particularly free jazz, is pleasurable for the individual musicians, it is important to realize that such pleasure is not derived from unbounded creativily, but from creativily that nevertheless retains strong fidelity to the form. Free jazz, as a music form, was not completely unanchored, but disciplined by a number of traditional features of jaz music. For a discussion of structural contours of the free jazz form, see discussion infro Part II.A.

14. See, e.g., John Hart Ely, Democracy and Distrust: A Tileory of Judicial Rleviliw

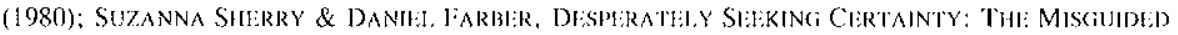

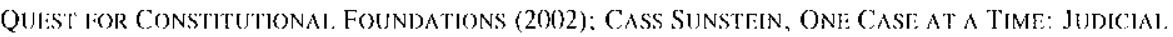
Minimailsm on the Supremi: CoukT (1999): Rebeca Brown, Liberty: The New Equality, 77 N.Y.U. L. RI:V. 1491 (2002),
} 
thinking constructively about how to improve adjudication in this context that I offer these thoughts.

Similarly, this Article is not intended as a defense for "liberal" activism in the civil rights context per sc. Rather, my principal concern is that judges, when asked to decide cases in which the rights of minorities are at stake, do not reflexively indulge the status quo or path of least resistance, but affirmatively and forthrightly act in a manner consistent with the best of the American constitutional tradition. I advance a particular model of democratic engagement in cases where minority rights are pitted against majority rule-the antisubordination principle-but I appreciate that our Constitution allows for multiple theories of democracy and conceptions of liberty and equality. ${ }^{15}$

This Article proceeds in three parts. In Part I, I sketch out the basic contours of the antisubordination principle, and argue that judges committed to realizing democracy for members of socially disfavored groups should embrace an antisubordination interpretation of the Fourteenth Amendment and the Courl's equality jurisprudence. In Part II, I present some preliminary ideas on how judges might successfully adjudicate constitutional cases that pit the rights and interests of socially disfavored and minority groups against majority rule in a manner consistent with the best of the American democratic tradition. Drawing upon the insights and impressions of free jazz musician Ornette Coleman, I argue that the hallmarks of Coleman's work-freedom, improvisation, reimagination, and courage--serve as useful points of departure for deepening our understanding of what judges committed to realizing democracy for members of subordinated groups do or ought to do. Part III concludes.

15. For instance, the majority of the Justices contime to interpret the Court's equality jurisprudence as based upon the principle of "colorhlindness." See Adarand Constructors, Inc. v. Penat 515 U.S. 200, 239 (1995) (Scalia, J., concurring) ("In the eyes of governmem, we are just one race here. It is American."); Adarand Constructors, 515 U.S. at 240 (Thomas, J., concurring) ("As far as the Constitution is concerned, it is irrelevan whether a government's racial classifications are obawn by those who wish to oppress a race or hy those who have a sincere desire to lielp those though to be disadvantaged." ): City of Richmond v. J.A. Croson Co., 488 U.S. 469, 518 (1989) (Kennedy, J., concurring) ("The moral imperative of racial neutrality is the driving force of the laqual Protection Clause."): J.A. Croson, 488 U.S. at 521 (Scalia. J., concurring) ("Our Constitution is color-blind"" (quoting Plessy v. Ferguson, 163 U.S. 537. 559) (1896) (Harlan, J., dissenting)): Metro Broadcasting, Inc. v. FCC, 497 U.S. 547, 602-03, 609-10 (1990) (O'Comnor, J., dissenting) ("Benign racial classification' is a contradiction in terms." ).

Many scholars support the Court's presem orientation on this issue. See, e.g., Strephan THi:RN. STROM \& ABIGAIL. THIERNSTROM, AME:RICA IN BI.ACK AND WIITTI: ONI NATHON, INDIVISIBII.E 539 (1997) ("Race-conscious policies make for more race-consciousmess; they carry American society hackward."). However, a number of seholars have pointed out the more pernicious consequences of the Court's adherence to a theory of "colorblindness." See, e.g., Neil Gotankla, A Critique of "Our Constintion is Color-Blind," 44 STAN. L. REv. I (1991) (arguing that the metaphor of "Our Constitution is Color-Blind" fossters racial domination): Jerome McCristal Culp. Jr., Colorblind Remedies and the Intersectionality of Oppression: Policy Argumens Masquerading as Moral Claims, 69 N.Y.U. I.. REV. 162 (1994) (arguing that colorblindness is a myth which we construct in order to deal with the moral dilemma of a racially stratified society). 


\section{DEMOCRACY, ANTISUBORIINATION, AND THE STAKES OF CONSTITUTIONAL ADJUDICATION}

Judicial interpretation of constitutional provisions intended to protect minority rights and interests against encroachment by the will of the majority continues to serve as a rich source of debate among judges, lawyers, and academics. "For more than forty years, constitutional theorists have struggled with this question of how to reconcile active judicial review with democratic theory. The problem, articulated by Alexander Bickel in The Least Dangerous Branch, is that "[j]udicial review . . . is the power to apply and construe the Constitution, in matters of the greatest moment, against the wishes of a legislative majority, which is, in turn, powerless to affect the judicial decision." 17 Bickel's trenchant criticism was followed up with claims advanced by William Rehnquist, Robert Bork, and others that unelected judges who ground their decisions in values not expressly stated or implied in the Constitution violate the fundamental democratic principle of majority rule. ${ }^{18}$ According to this view, constitutional interpretation and judicial review is legitimate only insofar as it is made consistent with majority rule. ${ }^{19}$ Not only did these scholars counsel judicial restraint in constitutional cases "of the greatest moment," but suggested that the line of activist decisions designed to protect minority interests were illegitimate and destructive of democracy. The predictable response among progressive scholars was to defend these decisions by offering theories of constitutional interpretation and judicial review that reconciled activism with

16. For a useful history of the contemporary debate over judicial review, see LAURA KAI.MAN,

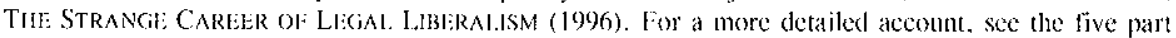
series of articles by Barry Frieclman. The History of the Commermajoritarion Difficulty, Part One: The Rocat to Indicial Supremacy. 73 N.Y.U. L.. REV. 333 (1998); The Histery of the Commermajoritarian Difficulty. Part Two: Reconsmation's Political Coum (manuscript on tile with author): The History of the Cotmermajoritarian Difficulty, Part Thee: The Lessom of Lochner, 76 N.Y.U. L. REV. 1383 (2001): The History of the Comtermajoritarian Difficuly, Pam Four: Law's Politics, 148 U. PA. L. RLV. 971 (2000); The History of the Commermajoriatian Difficulty, Part Five: Birth of an Academic Obsession, 112 Y Al.t: L. J. 153 (2002) (hereinafter, Friedman, Part Fivel.

17. Ali:Xandir Bicktei, The l.east Dangerous Brancil 20 (1962).

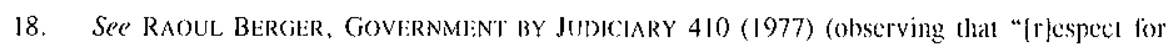
the limits on [juclicial] power are the essence of a democratic society"); Robert Bork. Nentral Principles and Some First Amendmem Problems. 47 IND. L.J. 1, 6 (1971) (stating that "a Court that makes rather than implements value eloices cannot be squared with the presuppositions of a democratic sociely"); William Rehnquist. The Notion of a living Constitution. 54 Trix. L. Rrav. 693, 695-96 (1976) (noting that "the ideal of judicial review has hasically antidemocratic and antimajoritarian facets that require some justification in this Nation").

19. But as Barry liedman perceptively notes, these advocates of the majoritarian approach do not seem particularly concerned with realizing democracy in a serious way. See Friedman. Pant five, supra note 16, al 164-65 ("Most constitutional scholarship in which the countermajoritarian difficulty is discussed is not even actually devoted to examining the question of whether judicial review is consistent with democracy in any deep philosophical or theoretical sense. In some instances, I the countermajoritarian diflieulty serves only as a backdrop for a theory of judicial review that advances the atuhor's own conception of what constitutional courts should-mor more recently should not-do."). 
majority rule. ${ }^{20}$ Others suggested that the inquiry into the legitimacy of judicial review was "futile and dangerous," and sought to re-center the debate on the appropriate level of discretion that should be granted to judges deciding constitutional cases. ${ }^{21}$

What is clear from both sides of this debate is that in "matters of greatest moment," where minority rights are pitted against majority will, it matters a great deal how judges approach the task of constitutional interpretation. At these moments, judges play a crucial role in shaping American democracy. At the heart of this debate, then, are questions about the nature of our constitutional democracy as it applies to minority interests and the role of judges in that democracy.

The Constitution is neither neutral nor ambivalent toward the protection of minority rights. In many ways, equality jurisprudence has mediated the tension between judicial protection of minority rights and majority rule-the norm of equality may impose constraints upon political majorities and their representatives..$^{22}$ This realization came about, in large part, in response to flagrant injustice arising from the denial of equal treatment to African-Americans in this country. The freedom struggle for blacks highlighted these injustices, and proved that, when the rights of cultural minorities are at stake, society could not reasonably rely upon majority rule to check the will of the majority. ${ }^{23}$ The Court's decision in Brown $v$. Board of Education ${ }^{24}$ signaled the Court's most prominent break from majority rule in the name of protecting minority interests, much to the disappointment of majoritarians.

The Court's decision in Brown, as well as in other cases, is rooted in an appreciation of the principle of antisubordination embodied in the Fourteenth Amendment and the Court's equality jurisprudence. The thrust of the antisubordination principle is that a law is objectionable on equality

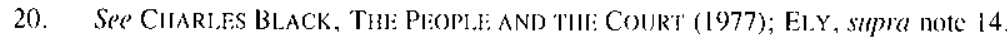

21. Erwin Chomerinsky, The Price of Asking the Wrong Question: An Essay on Constiunional Sitholarship and Judicial Review, 62 Tex. L. REv. 1207, 1209 (1984).

22. See, e.g., LAURI:NeI: H. TRIBI:, AMERICAN CONSTITUTIONAI. I.AW \$\$ 16-13 10 16-16 (2d ed. 1988). But see Adarand Constructors, Inc. v. Pena, 515 U.S. 200, 227, 255, 271 (1995) (holding that all racial classifications are subject to strict scrutiny, while dissenters argued lor greater deference 10 legiskature when such classifications are benign or remedial).

23. Ses, e.g., LEARNIID JAAND. THE BILL OI: RIGHTS 54-55 (1958) (criticiring lhe Court in Brown for overruling legislative judgments of states); Alexander M. Bickel, The Original Understanding and the Segregation Decision, 69 HARv. L. REv, 1, 58-59 (1955) (discussing how the Court in Brown ignored history of the Iourteenth Amendment that showed clear congressional purpose to permit segregation); Charles L. Black, Jr., The lawfulness of the Segregation Decisions. 69 Y Al.I: L.J. 421. $424(1960)$ (defending Brown on ground that state segregation laws were intentionally and inevitably discriminatory). At the same time, Brown was criticized ats an unprincipled opinion. See Herhert Wechsler, Toward Nemral Principles of Constimional Law, 73 HARV. L. REV, 1, $31-33$ (1959) (questioning the neutrality, and henee the legitimacy, of Brown). But see Louis H. Pollak, Racial Discrimination and Judicial Inegrity: A Reply to Professor Wechster, 108 U. PA. L. REv. 1, 31-32 (1959) (refuting neutality as basis for resolving equality issues raised by Bown).

24. 347 IJ.S. 483 (1954). 
grounds if it has the effect of creating or reinforcing second-class citizenship on the basis of race, ethnicity, gender, or similar category. The classic statement of the antisubordination principle was articulated by Professor Owen Fiss, who argued that the Equal Protection Clause prohibits a law or official practice that "aggravates (or perpetuates?) the subordinate position of a specially disadvantaged group." ${ }^{25}$ More recently, Professor Cass Sunstein has argued that the antisubordination principle is rooted in the demonstrable purpose of the Fourteenth Amendment to eliminate racial caste. ${ }^{26}$ Professor Akhil Amar similarly points out, "|T] he Fourteenth Amendment framers clearly aimed to prohibit [the Black Codes] as a paradigm case of impermissible legislation." ${ }^{27}$ Thus, one can quite sensibly interpret the Equal Protection Clause as prohibiting only governmental actions that subjugate or subordinate racial groups, and not remedial actions that help groups subjected to discrimination and subordination. Focusing on issues of race and gender, Sunstein explains, "Instead of asking 'Are blacks or women similarly situated to whites or men, and if so have they been treated differently?' we should ask 'Does the law or practice in question contribute to the maintenance of second-class citizenship, or lower-caste status, for blacks or women?"28 Other scholars, including Professors Robin West and Dorothy Roberts, have similarly advanced the antisubordination principle. ${ }^{29}$

An appreciation of our constitutional commitment to antisubordination $^{30}$ suggests that judges who take democracy seriously ought to be vigilant in their protection of minority interests. This is true not only because

25. Owen M. Fiss, Groups and the Equal Protection Clanse, 5 PHIl., \& PUB, AFF. 107, 157 (1976).

26. Cass R. Sunstein, The Antcaste Principle, 92 MICH. L. Røv. 2410, 2429 (1994) fhereinatter Amicaste Principle|.

27. Akhil Reed Amar. The Supreme Coum, 1999 Tarm-Foreword: The Document and the Doctrine, 114 HARV. L. REV. 26, 64 (2000); see also Michad W. McConnell, The Importance of Hemiity in Judicial Review: A Comment on Romald Dwerkin's "Moral Reading" of the Constitution, 65 Foridram L. Rev. 1269, 1281 (1997) ("The clearest and most indispulable purpose of the Fourleenth Amendment was to provide constitutional authority for the Civil Rights Act of 1866 , which outlawed the Black Codes.").

28. Anticaste Principle, sitpra notc 26, at 2429 (1994).

29. See Dorothy E. Roherts, Pumishing Drug Addicts Who Have Babies: Women of Color, Equality, and the Right of Privacy, 104 IlARV. I. REv. 1419, 1453-54 (1991) (ohserving that "the antisubordination approach considers the concrete effects of government policy on the substantive condition of the disadvantaged"); Robin West, Progressive and Conservative Constitutionalism, 88 Micil. I. REv. 641, 694 (1990) (arguing that "'le|cual protection," lor the progressive, means the eradication of social, economic, and privale, as well as legal, hierarchies that damage").

30. The antisubordination principle has been acknowledged by the Supreme Court. See e.g. Adarand Constructors, Inc. v. Pena, 515 U.S. 200, 243 (1995) (Stevens, J., dissenting) ("There is no moral or constitutional equivalence between a policy that is designed to perpetuate a caste system and one that seeks to eradicate racial subordination."); Strauker v. Virginia, 100 U.S. 303. 307 (1880) (the pervading purpose of the Civil War Amendments was to outlaw discrimination against a once-enslaved race). However, the majority of the Rehnipuist Court has rejected this reading of the Court's equality jurisprudence. For a sampling of the Court's recent decisions advancing the principle of colorblinklness in lieu of the antisubordination primciple. see stpra note 15. 
judges have, in this century, been the primary guardians of minority rights against majority encroachment, ${ }^{31}$ but also because democratic government and judicially-enforced minority rights are both based upon a single conception of respect owed to every individual by the government. Respect for equal citizenship requires that judges, in the name of democracy, be wary of the potential for minority rights to be lost in what Professor Charles Black described as "the hard fighting which is another aspect of the American political tradition." 32 As Jack Balkin so eloquently cxplains:

Democracy is more than just a matter of letting majorities have their way . . . . It is . . . a theory about the proper organization of society and the proper mode of social relations. . . This deeper, substantive, and cultural vision of democracy is and must be opposed to unjust social hierarchy and caste, even when supported by a majority of citizens, and even when justified by appeals to morality and tradition..$^{33}$

Constitutional adjudication that strives to realize democracy, then, encourages courts to embrace the antisubordination principle when deciding cases that pit minority rights and interests against majority rule. Under this view, the issue is not whether judges should seek to protect minority interests over the objection of members of the majority when the majority seeks to promulgate some law that subordinates or reinforces the subordinated status of a social minority, but in what manner should they go about doing so. So, how should courts proceed in the face of social forces that counsel restraint, or even worse, encourage the sacrifice of minority interests on the altar of majority rule? For inspiration on how to realize democracy through judging, one might profitably draw upon the experience and impressions of individuals who strive to realize democracy in another medium: jazz.

\footnotetext{
31. See United States v. Carolene Prods. Co., 304 U.S. 144, 153 n.4 (1938) (arguing that people of color were "discrete and insular" minorities who, because of their small mumbers, were powerless to affect the political process and, therefore. required courts to serve as guardians to protect their

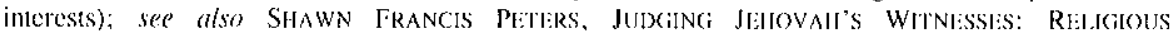
PERSEECUTION AND THI: DAWN OF THF: RkiltTS REVOIUTTION 293 (2000) (observing that under the Chief Justiceship of Fant Warren, "the Supreme Coure at last became a zealous guardian of individual and minority rights."). But see Mo., Kan., \& Tex. R.R. Co. v. May, 194 U.S. 267, 270 (1904) (articulating Justice Holmes's view that "it must be remembered that legislatures are ultimate guardians of the liberties and welfare of the people in quite as greal a degree as the courts. "): THI: FIDI:RALIST No. 78, at 433 (Alexander Hamilton) (Clinton Rossiter ed. 1999) (expressing the Framers' belief that the Court is the "the least dangerous" branch to the political rights of American citizens).

32. BI.ACK, supra note 20, al 105

33. Balkin, supra note 8 , at 2368 .
} 


\section{THE JAY\% CONNECTION}

Amiri Baraka once remarked that the spirit of jazz music is "essentially the expression of an attitude, or a collection of attitudes, about the world, and only secondarily an attitude about the way music is made." ${ }^{3.4}$ It should come as little surprise, then, to learn that musicians themselves view jazz as a metaphor for denocracy. Consider, for instance, Wynton Marsalis's explanation of how members of a jazz ensemble relate to one another in order to produce a distinctive musical expression:

In American life ... we have all of these different agendas; we have conflict all the time and we're attempting to achieve harmony through conflict. It seems strange to say that- - but it's like an argument that you have with the intent to work something out, not an argument that you have with the intent to argue. And that's what jazz music is-[we] . . have musicians, and they're all standing on the bandstand, each one has their personality and their agenda. Invariably they're going to play something that you would not play, so you have to learn when to say a little something, when to get out of the way. So you have that question of the integrity, the intent, the will to play together-that's what jazz music is. So you have your self, your individual expression, and then you have how you negotiate that expression in the context of that group and it's exactly like democracy. ${ }^{35}$

Jazz functions as democratic expression insofar as it demonstrates "how the individual can negotiate the greatest amount of freedom and put it humbly at the service of a group conception." 36 Or, to paraphrase Charles Henry's observation in Culture and African American Politics, the significance of jazz is that it provides a group structure that enables a great deal of freedom and improvisation, although that freedom is nevertheless bound and contingent upon the purposes of the other members of the ensemble..$^{37}$

Musicians are not alone in their appreciation of jazz as a metaphor for the richness of democratic possibilities. Professor Lani Guinier has used jazz as a metaphor for conversation and community when arguing for implementing the Voting Rights Act in a way that expands "participatory democracy." 38 According to Guinier, American democracy should strive

\footnotetext{
34. JONES, supra note 12, at 13.

35. Marsalis, supra note 12 .

36. Thomas Sancton, Horns of Plent, Timi, Oct. 22, 1990, at 70).

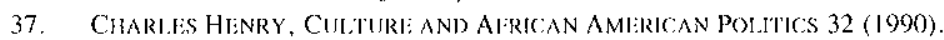

38. Lani Guinier, More Democracy, 1995 U. Coll. I.licial. F. I passim (1995).
} 
to emulate the sense of balance and community lound in jazz. ${ }^{39}$ Professor John Calmore invoked avant-garde tenor saxophonist Archie Shepp and his "fire music" of the 1960s as a means of describing both the posture of critical race theorists and their struggle to gain inclusion in the hall of academia. ${ }^{40}$ Former President William Jefferson Clinton described jazz as the voice of the American spirit because of its dialectic relationship with American history. ${ }^{41}$ A number of cultural critics have similarly argued that the American political tradition might be more powerfully understood when viewed in conjunction with the American jazz and blues tradition. ${ }^{42}$

If we understand jazz as reflective of the best of the American democratic tradition, then perhaps the most inspiring, liberatory figure in this metaphorical arrangement is Ornette Coleman-the consensus pioneer of "free jazz." 43 There is something deeply admirable about persons who self-consciously and intelligently challenge a prevailing set of orthodox arrangements. Coleman's graceful assault on the regimented styles that dominated the traditional jazz scene in the 1950s and 1960s is one of the more dignified examples. Coleman offered a transformative vision that tested the boundaries of the musical form while it simultaneously embraced the best of the historical improvisational tradition. ${ }^{44}$ Coleman's debut album Something Else?, his 1959 releases Tomorrow is the Question!, The Shape of Jazz To Come, and Change of the Century, and the prophetic double-quartet Free Jazz, released the following year, provide the core of Coleman's musical manifesto. ${ }^{45}$ If the bebop idiom could be understood as exemplifying the best of the prevailing state of orthodox jazz,

\footnotetext{
39. 1 ld.

40. John O. Calmore, Critical Race Theory, Archie Shepp, and Fire Music: Securing an Authentic Inellectual Life in a Multicultural Workd, 65 S. CAL. L. RIV. 2129-2230 (1992). For an interesting discussion that extends Calmore's project, see Jomathan A. Beyer, The Second Lime: Reconstructing the Jaze. Metaphor in Critical Race Theory, 88 Giro. I.J. $537-63$ (2000) (using lhe work of Duke Ellington and the metaphor of the "jaz7. republic" 10 move the project of Critical Race Theory from (spposition and critique to pluratistic association and reconstruction).

41. President William Jeferson Clinton, Remarks by the President and the First Lady at the White House Miltennium Evening Lecture Series (Sep). 18, 1998) (transcript available in Federal Document Clearing Hose Federal Deparment and Agency Documents).

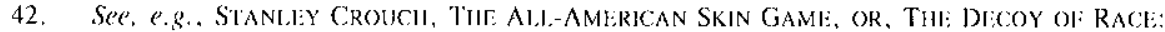
THE LONG AND THE SHORT OI: IT 10-20 (1995) (suggesting a dialectic relationship among jazz, blues, constitutional listory, and American democracy); RALPII El.ISOSON, Bhes People, in SHAdOW ANI) Ac'T 247-58 (Vintage ed. 1972) (discussing and critiquing LeRoi Jones's view on the linkage between ideology and the American jazz and blues tradition); AI.BERT MURRAY, THI: OMNIAMI:RICANS: NI:W

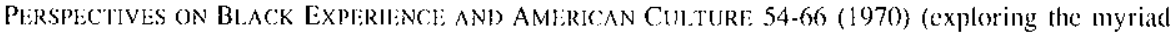
ways in which the blues idiom linds expression in contemporary social and political life); CorNEl. WEST, On Afio-Americam Music: From Bebop to Rap, in PROPIIITIC: FrAGMIinTs 177-87 (1988) (analyzing shifts in African-American popular music against the backdrop of changing socioeconomic political conditions).

43. PETER N. WIISON, ORNETTE COII:MAN: IIIS I IFI: ANI) MIISIC 35 (1999).

44. WILSON, stipra note 43, at 36.

45. AI.YN SHIPTON. A NEW HISTORY OF JA7.7. 180, 783 (2001). Coleman's career has spanned more than forty years, and he continues to write music
} 
Coleman's searing sounds constituted a blistering critique and vision of transcendence that could only be achieved by first coming to terms with the essential concepts of freedom, creativity, and humanity that underlies all musical forms. As Coleman explains, "When you hear me, you probably hear everything I've heard since from when I was a kid. In fact, it's a glorified folk music." 4

Among the pantheon of jazz luminaries, there have been essentially three artists whose presence dramatically transformed the course of jazz history: Louis Armstrong, Charlie Parker, and Ornette Coleman. ${ }^{47}$ Louis Armstrong's late 1920 s inventive musical masterpieces gave form and meaning to jazz as distinctive from other forms of American popular music. ${ }^{48}$ It was Armstrong that moved jazz from the margins to the center and inspired the Swing era. ${ }^{49}$ Two decades later, Charlie Parker offered a new lyricism, energy, and harmonic structure that moved the jazz form to new heights of artistry. ${ }^{50}$ Fifteen years later, Coleman's musical approachpremised upon the musical principle that the pattern for the tune will be forgotten, and the tune itself will be the pattern-questioned the very foundations of what many of his contemporaries understood jazz music to be. ${ }^{51}$ Coleman's work shaped a number of prominent traditional jazz musicians of the day, including John Coltrane. ${ }^{52}$ It may be a bit of an exaggeration to denominate the years following the release of Coleman's Something Else! as "the Ornette Coleman era," but the arrival of Coleman marked a watershed moment in jazz history and in the years since "no other jazz artist's work has had anything approaching equal resonance." ${ }^{53}$

What follows is a discussion of the salient features of Coleman's approach to free jazz, and how these features might prove useful in thinking about both the style and substance of constitutional adjudication in cases where minority rights are pitted against majority will.

\section{A. Freedom}

At the heart of Coleman's contribution to contemporary music is the emphasis upon freedom. Indeed, as some writers have found, it is difficult

\footnotetext{
46. WII.SON, silpra note 43, at 20.

47. SHIPTON, shipra notc 45, al 774.

48. ICl. at $586-89$.

49. Id. at 411 .

50. Id. at 455 .

51. Il. al 774 .

52. See fadd first namel Goldberg, Jaz7. Masters of tife FifTtes 204-06 (1965); ShtPron, supro note 45 , at 754-55, 791. Colcman, of course, had a more intimate following that included trumpeter Don Cherry, tenor saxophonist Archie Shepp, bassist Charlie Haden, and others, For an interesting account of the life and music of Archic Slepp. and its relationship to Critical Race Theory, see Calmore, supra note 40 .

53. JOIIN I.ITWIIILR, ORNETTE COI.HMAN: A HARMOI.ODIC LIIE 16 (1992).
} 
to mention the phrase "free jazz" without some mention of Ornette Coleman, as his name has become virtually synonymous with the movement. ${ }^{5.4}$ As a pioneer of "free jazz." Coleman's innovativeness derived from his ability to question musical conventions. ${ }^{55}$ Indeed, "[I]t is precisely because $\mathrm{Mr}$. Coleman was not 'handicapped' by conventional music education that he has been able to make his unique contribution to contemporary music." ${ }^{56}$ Or as Billy Higgins, drummer in Coleman's first quartet remarked,

He really opened up my mind, because, as far as conventional playing is concerned, everything just comes down to 4- 8- 16- or 32-bar phrases. He started writing things that were 11 bars or 6 . If you listen to it, it's natural, too, but it kind of made you think another way. ${ }^{57}$

Coleman was profoundly aware of the power that resides in freedom as concept, and fashioned an entire approach around it. In the liner notes to his album Change of the Century, Coleman writes:

Each player is free to contribute what he feels in the music at any given moment . . . I don't tell the members of my group what to do. I want them to play what they hear in the piece for themselves. I let everyone express himself just as he wants to. The musicians have complete freedom . . . 58

Freedom for Coleman meant flexibility in approaching compositions. As Coleman himself once remarked, "I would prefer it if musicians would play my tunes with different changes as they take a new chorus, so that there'd be all the more variety in the performance." ${ }^{59}$ This liberatory, organic aesthetic was both readily apparent and attractive to a number of his fellow musicians. ${ }^{60}$ As pianist John Lewis relates, "It didn't take me more than a second to realize that [Coleman's project] was the missing link be-

54. ShImTON, supre note 45, at 778-90; WIISON, supra note 43, at 34. Of cotrse, there were a number of musicians experimenting with "frec jaz7" around the same time as Coleman. For instance, "Charles Mingus experimented with new, multi-part thematic structures" and "extended lorm" improvisation. WILSON, simera note 43, at 39. Jolon Coltrane was becoming increasingly reknown for deconstructing traditional bebop phrasing into harmonic "sheets of sound." /d. at 40. Interestingly. Coleman once confessed in an interview dlat "I never called the music that I wrote "free jaz\%." $/ d$, at 34.

55. WILSON, sitpra note 43, al 34-40.

56. Gunther Schutler, Musincis: ']he Musical, Wortdos of Gunther SChulder 80-81 (1986).

57. WILSON, supra note 43 , at 36

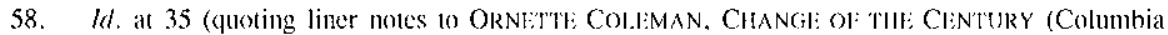
196()$)$.

59. SCIIULLER, smpra note 56, at 83.

60. SHIPTON, sipra note 45 , at 779 
tween playing totally free, without any givens, and playing bebop, with steady changes and steady time." ${ }^{61}$

Although Coleman's music was fundamentally free, it was not entirely unanchored. Besides the fact that Coleman's music was written down much like any conventional musical score, much of Coleman's musical expression was firmly rooted in the traditional forms. ${ }^{62}$ As his biographer Peter Wilson recounts, much of Coleman's compositions tracked traditional brass band fanfares, blues riffs, and southwestern popular motifs and melodies. ${ }^{63}$ Additionally, the characteristic sound of Coleman's saxophone is often described as having a "talking" expressive quality reminiscent of a blues chant. ${ }^{64}$ As Charles Mingus once observed, "|Coleman is| really an old-fashioned alto player. He's not as modern as Bird." ${ }^{65}$ By this, he meant that Coleman's sound was that of a human voice played on his plastic alto sax, a sound intended to reflect the moans, shrieks, hollers, and laughs of the blues.

Perhaps most revealing of Coleman's self-imposed limits upon freedom was his adherence to certain musical conventions. As Wilson eloquently describes:

Coleman's music around 1960, even on Free Jazz, is subjected throughout to a traditional beat; in fact, the rhythm is often so clear and straightforward that it harks back to jazz before bebop; the received hierarchy of horns and rhythm section is still largely honored; and the traditional sequence of theme-solos-theme is mostly still adhered to . . . .6

For these reasons, it was clear to Wilson that "[t]he musical rules in Coleman's music are so obvious and of so traditional a kind-whether they are now explicitly enforced or intuitively followed-that the 'free' in 'free jazz' can only be understood in a limited, relative sense," ${ }^{67}$

There are two relevant aspects to freedom here. First, there is the freedom that Coleman seeks in terms of his ability to shape the musical form. Here, freedom takes the form of experimenting in terms of composition. But there is a second, deeper aspect of freedom that is embodied in content of Coleman's musical experience. Freedom informs not only the process of making music, but functions as the substantive aim of the free jazz enterprise. The form of the music is itself an expression, if not the

\footnotetext{
61. Id.

62. WILSON, supra note 43, al 20.

63. Id.

64. SCHUII.FR, sipra note 56, at 78 .

65. GOI.JBBi:RG, supra notc 52, at 237.

66. WIISON, sipra note 43, at 35-36.

67. Id. at 35 .
} 
embodiment, of freedom. In this way, freedom is reflected in both the form and substance of Coleman's music.

These twin notions of freedom are useful when thinking about constitutional adjudication when minority rights are at stake. Judges should not only indulge the possibility of questioning majority will; they should do so in a manner that places a premium on achieving the substantive ends of freedom. Interestingly, both freedom in terms of process and freedom as substantive end are captured in the antisubordination principle. As Sunstein has written, the legal concept of freedom can be understood both in terms of equality and in terms of liberty. ${ }^{68}$ Freedom in the context of equality might be understood as freedom from differential treatment on the basis of race or gender, or equality of process, or similar starting point or basic opportunities for every citizen. ${ }^{69}$ Freedom in the liberty context might be understood in the libertarian sense of freedom to pursue one's own ends without government intrusion. ${ }^{70}$

Yet, as Sunstein and others persuasively argue, notions of liberty and equality are not necessarily in tension with one another and, indeed, converge in the area of antisubordination. ${ }^{71}$ This is because the antisubordination principle embodies both the process/equality component of freedom and the liberty/substantive aspect of freedom. The former is reflected in the prohibition on actions that aggravate or perpetuate subordination. The latter is embodied in the affirmative mandate to take action that eliminates present subordinating conditions. In this way, the antisubordination principle is not only consistent with our equality jurisprudence, but "fits well with the best understandings of liberty."72

In the jazz context, these twin notions of freedom are manifested in the challenging, flexible approach to creating music that is expressive of freedom, but remains anchored and disciplined by music form. In the civil rights context, the judge committed to realizing democracy for subordinated groups should accent flexibility in her decision making that is anchored and disciplined by the antisubordination principle. The judge who seeks to realize democracy on such occasions must understand and acknowledge her central role as the ultimate guardian of minority rights and interests. From this perspective, the principle task of judges in a modern constitutional democracy is, as Professor William Eskridge has argued, "to protect the integrity of the pluralist political process, and especially to check the political process' tendency toward self-perpetuation and persecution or suppression of minorities. "73

\footnotetext{
68. Anicaste Principle, supra note 26, at 2410-11.

69. Id. at 2410 .

70). Id. at 2411 .

71. Id. at 2410 .

72. Id. at 2412 .

73. Eskriklge, supra, note 6, at 2068.
} 


\section{B. Improvisation and Reimagination}

Music critics continue to debate the merits of Coleman's technical contribution to contemporary music. However, most agree that the distinctiveness of his approach is derived from his heavy reliance upon improvisation. ${ }^{74}$ Although improvisation had been a hallmark of jazz since its inception, ${ }^{75}$ Coleman's approach is exceptional insofar as the musical form itself is defined by the scope and contour of the improvisation. As biographer Peter Wilson explains: "The nature of improvisation, in Coleman's view, is incompatible with pre-determined patterns, be they harmonic, rhythmic, or structural; the pre-existent form should not determine the improvised line, the improvisation should instead create the form. "76

Coleman himself views his reliance upon improvisation and reimagination of the musical form as part of a larger theory of "Harmolodics"-a philosophical approach to music construction that combines insights from a number of idioms, including music, language, dance, time, and relativity to explain how a particular tone relates to another. ${ }^{77}$ However, as one commentator remarked, "Analysts of Coleman's work . . . have tended largely to disregard [Coleman's] theoretical ideas, and instead [] focus on his extraordinary instinctive genius for melody and for creating immediately identifiable improvisations on his main instrument, the alto saxophone." 78

Whether one views Coleman as operating out of a theory or mood or consciousness, one can appreciate the singular importance of creativity in his work. Creativity and imagination are useful concepts within the realm of constitutional adjudication. Judges interpreting the constitution when minority interests are at stake should appreciate that the task of realizing democracy entails, to a certain extent, the ability to project a vision of the future that may be incompatible with the present state of affairs. The ability to improvise and reimagine is exemplified by the Warren Court's approach to equal protection in Brown v. Board of Education ${ }^{79}$ Although the Fourteenth Amendment to the Constitution was understood as an effort to eliminate racial caste, it was not, at least up this point, understood as a presumptive prohibition on all race distinctions. ${ }^{80}$ The Court, however,

\footnotetext{
74. See SHIPToN, supra note 45, at 774 (asserting that "Coleman's principle innovation was to redirec the basis of jazz improvisation from the harmonic (or chord sequencel to the melodic").

75. Id. at 5-6 (Jar\% hegan as a collectively improvised music, with syncopated rhythms over a strong unklerlying pulse, involving the use of some notes in both its melodies and hamonies that are flattened to a degree smaller than a semitone. . . which have come to be known as "blue' notes. . . ").

76. WII.SON, silpra note 43, at 37.

77. See SHIPTON, stapra note 45 , at 775.

78. $1 d$

79. 347 U.S. 483 (1954).

80. Anticaste Principle, supra note 26, at 2435-36.
} 
understood that race distinctions such as segregation in public schools had catastrophic meaning in the eyes of many African-Americans. Rather than adhere to a constitutional interpretation that, in many ways, mocked fundamental notions of equal citizenship, the Court embraced a vision of the Fourteenth Amendment that sought to realize democracy. As the Court explained, "In approaching this problem, we cannot turn the clock back to 1868 when the Amendment was adopted," but instead should look to resolve the question of equal protection in the context of contemporary American life. ${ }^{81}$

The Court faced a similar conundrum in Bolling $v$. Sharpe. ${ }^{82}$ The Court had already held segregation in public schooling unconstitutional in the states. ${ }^{83}$ Surely, segregation in public schooling in the District of Columbia was equally problematic and worthy of condemnation. Yet, the textual hook of the Fourteenth Amendment did not reach into the federal setting. Once again, the Court relied upon its ability to improvise and reimagine the constitutional landscape, finding that the principle of antisubordination embodied in the Equal Protection Clause of the Fourteenth Amendment was likewise reflected in the Due Process Clause of the Fifth Amendment. ${ }^{84}$

The decisions in Brown and Bolling were both heavily criticized as unprincipled, ${ }^{85}$ political, ${ }^{86}$ and thwarting the democratic process. ${ }^{87}$ Yet both decisions, in my mind, exude a deep respect for democracy, the antisubordination principle, and basic notions of equal citizenship. This effort on the part of the Warren Court to reimagine equality jurisprudence culminated in Loving v. Virginia, ${ }^{88}$ in which the Court struck down Virginia's anti-miscegenation laws. ${ }^{89}$ In his majority opinion, Chief Justice Earl Warren reasoned that Virginia's ban on interracial marriages was "designed to

\footnotetext{
81. Brown, 347 U.S. at 492.

82. 347 U.S. $497(1954)$.

83. Brown, 347 U.S. at 495.

84. Bolling, 347 U.S, at 499-500 (linding that racial segregation in public education constituted a deprivation of libery in violation of the Due Process Clause of the Fifth Amendment).

85. See Wechsler, supra note 23 (criticizing Brown as desirable but unprincipled).

86. This sort of criticism is exemplified by the short statement of resistance issued by Senator James Eastland of Mississippi following Brown: "|The South/ will not abide by nor obey this legislittive decision by a political court. We will take whatever steps are necessary to relain segregation in education." NAdine: Cohodas. Strom Tilurmond and till: Politics of SOlJThirn Change 254 (1993) (emplassis added).

87. For example, immediately following the Courl's decision in Bromn, ninely-six Southern congressmen issued a declaration calling the Court's decision a "clear abuse of |thel judicial power" in which the "federal judiciary [was| undertaking to legislate. in derogation of the authority of Congress." See Text of 96 Congressmen's Dectaration on Integration, N.Y. TIMEs, Mar. 12, 1956, at 19 (publishing the "Declaration of Constitutional Principles" issued by Southern congressmen),

88. 388 U.S. I (1967).

89. Loving, 388 U.S. at 12.
} 
maintain White Supremacy," and any such law would constitute a per se violation of "the central meaning of the Equal Protection Clause."

From this description, it might be tempting to conclude that improvisation and reimagination are features limited to one particular court, or simply artifacts of a bygone cra in which courts were unusually susceptible to social forces or an organized civil rights movement. But the Rehnquist Court, on at least one occasion, has demonstrated this capacity as well. In Metro Broadcasting, Inc. v. FCC, ${ }^{\text {'1 }}$ the Court was asked to review the Federal Communication Commission's telecommunication licensing policy. The FCC had adopted a limited race preference program to increase the number of minority owners of broadcast stations by giving minorityowned companies a "plus" in competitive license bidding and first crack at "distress sale" of licenses. ${ }^{2}$ The Court upheld the FCC's use of limited preferences on the ground that it was substantially related to achieving the important governmental objective of broadcast diversity. ${ }^{93}$ What makes the case so profound, though, is the sincere respect that the majority opinion exudes regarding the desirability of diversity both in the limited context of broadcasting and, more generally, in society. The Court's willingness to embrace the diversity rationale in this case signaled an acknowledgment and legitimation of multiculturalism in our lives. ${ }^{94}$

\section{Courage}

Shortly after his arrival in New York City, Coleman found himself at the center of what some contemporaries described as "the most violent controversy to divide the jazz. world since the arrival of Charlie Parker." 95 Coleman received strong praise from some reviewers. For instance, Martin Williams declared in Jazz Review: "I honestly believe . . that what Ornette Coleman is doing on alto will affect the whole character of jazz music profoundly and pervasively, and that the first consideration is that what he plays can be very beautiful." ${ }^{\circ 6}$ Most musicians and critics, writes jazz historian Joe Goldberg, "equivocated and evaded, not wishing to make the error of out-of-hand condemnation that many of them had made with [Charlie] Parker, yet unwilling to approve of music that offended and

\footnotetext{
90. Id. al $11-12$.

91. 497 U.S. 547 (1990).

92. Metro Broad, 497 U.S. al 557.

93. Id. at 566 .

94. For academic praise of the Metro Broadcasting decision, see T. Alexander Aleinikoff, $A$ Case for Race-Conscionshess, 91 Coldsm. L. Ri:v. 1060 (1991); Patricia J. Williams, Metro Broadcasting. Inc. v. FCC: Regrouting in Singular Times. $104 \mathrm{H} A \mathrm{RV}$. L. REV, 525 (1990). For a critical vicw of the decision, see Charles Fried, Metro Broadcasting. Inc. v. FCC: Two Concepts of Equality, 104 HARV. L. REV. 107 (1990).

95. GOLDBERT, supra note 52 , at 230 .

96. Id. at 229 .
} 
outraged them." 97 Some, however, were less than charitable. In a review of Coleman's Free Jazz, release in 1961, John Tynan remarked:

Where does neurosis end and psychosis begin? The answer must lie somewhere within this maelstrom. If nothing else, this witch's brew is the logical end product of a bankrupt philosophy of ultra-individualism in music "Collective improvisation?" Nonsense. The only semblance of collectivity lies in the fact that these eight nihilists were collected together in one studio at one time and with one common cause: to destroy the music that gave them birth. Give them top marks for the attempt. ${ }^{98}$

Milt Jackson, of the Modern Jazz Quartet, remarked of the critics' collective silence, "They're afraid to say [that Coleman's project] is nothing. . . . There's no such thing as free form." ${ }^{\text {"99 }}$ Miles Davis remarked, "Hell, just listen to what he writes and how he plays. If you're talking psychologically, the man is all screwed up inside." ${ }^{(0)}$ Audiences were also unsure what to make of Coleman's project. Paul Bley described Coleman's debut at the Hillcrest Club in 1958: "You could tell whenever the band was playing, because the audience would be outside on the sidewalk, and then when the intermission came, they'd go into the club for a drink." 101

Coleman's steadfastness in the face of criticism highlights the importance of courage when challenging a prevailing set of orthodox arrangements. Courage is equally important when confronting opposition in the law. The Civil Rights era was, in many ways, an era defined by judicial courage. Nowhere was such courage more pronounced than in the federal district courts of the Deep South. A number of district court judges, such as Judge Frank Johnson of Alabama and Judge J. Skelly Wright of Louisiana, demonstrated remarkable courage and steadfastness in upholding the Supreme Court's ruling when confronted with local resistance in the form of political subterfuge, legal evasion, and physical violence. ${ }^{102}$

97. Id at 230 .

98. WusON, supra note 43 , at 35 . Interestingly, the viscerally negative response to Coleman's work persisted over thinty years later. In an article in Down Beat magazine, John MeDonough writes of Coleman's Free Jazz. release that "Ij|azz had never produced a music in which fakes could move so easily and undetected among real musicians." Joln McDonough, Pro and Con, DOWN BEAT , January 1992, al 30-31, reprimed in KE:EPING TIME: READINGS IN JAZ7. HisTORY 397 (Robert Walser ed., $1999)$.

99. GOLDBERG, supra bote 52, at 231.

100. Id. al 231

101. Siltpron, stipra note 45, at 773 .

102. For a discussion of Frank Johnson, see ROBT:RT F. KFNNEDSY, JR., JUDGiE Frank M. JOHNSON, JR.: A BIOGRAPHY (1978); TINSI.EY E, YARBROUGH, JUDGE FRANK JOHNSON AND HUMAN Rigirts in Alabama (1981). For a discussion of Judge Wright, see ARThur Slitwyn Millik, A

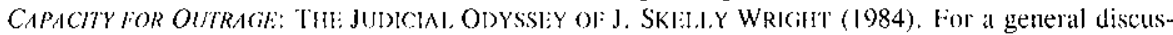
sion of Southern federal judges during this period, see JACK BASS, UNI,IKEI,Y HI:ROES (1981). 
The Supreme Court likewise exuded a profound sense of courage during this period. In Cooper v. Aaron ${ }^{103}$ the Court was confronted with the question of what to do with state officials that sought to interfere with the ability of local school boards to comply with the Court's ruling in Brown. The Little Rock school board had developed a desegregation plan in accordance with Brown, but on the day before this plan was to take effect, Arkansas Governor Orval Faubus posted National Guardsmen at the entrance of Little Rock's Central High School, and declared the school "offlimits" to colored students. ${ }^{104}$ The local U.S. Attorney sought and obtained an injunction against the governor to prevent him from using the National Guard as a means of stalling compliance with Brown. ${ }^{105}$ Ultimately, the President of the United States had to send in federal troops to ensure the safe admission of the black students at Central High. ${ }^{106}$ The desegregation plan generated high levels of hostility in the Little Rock community, leading to the request before the Court to stay its 1958 desegregation plan.

In an unprecedented opinion signed by all nine justices, the Court unanimously reaffirmed Brown and, notwithstanding its recognition of the "chaos, bedlam, and turmoil" in Little Rock, denied the request to stay execution of the desegregation order. ${ }^{107}$ Furthermore, the Court found that the adverse conditions were directly traceable to the behavior of state officials, and stated that such conditions could be brought under control by state action. The Court did not mince words: "It is emphatically the province and duty of the judicial department to say what the law is." 108 The Court stressed that constitutional law was binding over the states and that every state legislator and executive official has taken an oath to support the constitution. ${ }^{109}$ "No state legislator or executive or judicial officer can war against the Constitution without violating his undertaking to support it." 16

If Cooper exemplifies the Court during one of its more courageous moments, then the Court's opinions in Plessy v. Ferguson, ${ }^{11}$ United States v. Korematsu, ${ }^{112}$ and, more recently, Whren v. United States, ${ }^{13}$ provide examples of complacency and indifference. In Plessy, the Court declined

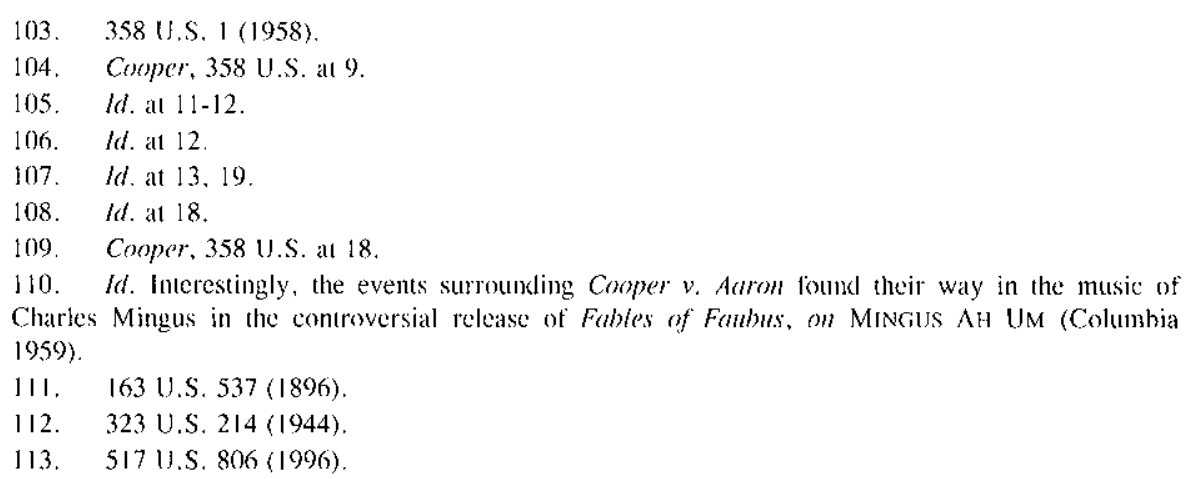


to invalidate a racially discriminatory Louisiana statute, choosing to allow the state legislature to defer to "the established usages, customs and traditions of the people, and with a view to the promotion of their comfort, and the preservation of the public peace and good order" when attempting to ascertain whether segregation on railroad cars was reasonable under the Fourteenth Amendment. ${ }^{1 / 4}$ Similarly, in Korematsu, the Court demonstrated a remarkable willingness to sacrifice the rights of citizens of color on the altar of military necessity, despite the clear racial overtones in the case. ${ }^{15}$ In Whren, the Court demonstrated a disturbing ability to turn a blind eye towards the practice of racial profiling, despite the admission by the government that traflic stops were used as a pretext for making stops of persons suspected of an offense for which there was no lawful basis to make a stop. ${ }^{116}$ In each of these cases, the Court expressed little, if any, real concern about the claims of injustice advanced by the parties.

Perhaps the Court's most glaring acts of evasion have taken place with regard to affirmative action in the educational context. The Court's most recent decision in this area is its controversial plurality decision Regents of the University of California v. Bakke ${ }^{117}$ where the Court upheld the constitutional validity of affirmative action in admissions to institutions of higher education, but struck down the specific program in the case. ${ }^{118}$ The splintered resolution in Bakke created uncertainty among federal courts not only as to the meaning of the decision, but its precedential value, as well. This uncertainty has swelled over years, in large part, because the Court has steadfastly denied certiorari in every single case following Bakke in which an educational affirmative action program was similarly challenged. ${ }^{119}$ However, at the time of this writing, the Supreme Court has granted certiorari to a case challenging the affirmative action policy at the University of Michigan School of Law. ${ }^{120}$

\footnotetext{
114. Plessy. 163 U.S. at 550

115. Korematsu, 323 U.S. at 223.

116. Whren, 517 U.S. at 813,819 .

117. 438 U.S. $265(1978)$.

118. Bakke, 438 U.S. at 320

119. See Smith v. Univ, of Wash., 233 F.3d 1188 (9h Cir. 2000), cent denied, 532 U.S. 1051 (2001); Eisenherg v. Montgomery County Public Sch., 197 F.3d 123 (4th Cir. 1999), cert. denied, 529 U.S. 1019 (2000): Tuttle v. Arlinglon Counly Sch. Bd., 195 F.3d 698 (4ll Cir. 1999), rert. denied. 529 U.S. 1050 (2000); Hunter v. Regents of the Univ. of Ca., 190 F.3d 1061 (91h Cir. 1999), cent denied. 530 U.S. 877 (2000); Hopwool v. Texas. 78 I.3d 932 (51h Cir. 1996), cent denied, 518 U.S. 1033 (1996). A similar challenge to The University of Georgia's admissions policy was presented in Johnson v. Board of Regents of University of Georgia. 263 F.30 1234 (111h Cir. 2001). Despite the lileventh Circuit's invalidation of the program on narrow tailoring grounds, the parties declined to seck review hefore the Supreme Court. See Johnson, 263 F. 30 at 1244-45.

120. Grutter v. Bollinger, 288 F.3d 732 (6th Cir. 2002), cert granted, 123 S. C. 617 (2002). There was also a group of intervening delendants in the case involving undergraduate admission to the University of Michigan. See Grat\% v. Bollinger, 22 F. Supp. 2d 811 (E.1). Mich. 2000). However, their claim was limited to the argument that the undergraduate affirmative action program was to remedy the university's past discrimination against minorities. Gratz. 122 F. Supp. at 814 n.3. That
} 
A judge that seeks to realize democracy in constitutional adjudication in moments of great importance cannot dodge this difficult question, but must muster the courage to face it head on because society is so deeply in need of guidance on this point. Note that courage does not demand a particular ideological result. Whether rightly or wrongly decided, courage demands that judges step boldly into the fray of group conflict that is, in many ways, the sine qua non of democratic life. This highlights an important second dimension to courage of the sort we are talking about here as well. Courage, in a very real sense, requires judges to indulge the possibility of getting the decision wrong. But facing the question, and clearly getting it wrong, might also serve as the path to the correct outcome. When questioned about the legitimacy of free jazz, Ornette Coleman responded, "It was when I found out that I could make mistakes that I knew I was on to something." 121

There is, of course, a thin line between courage and arrogance. It is easy to imagine a world in which a courageous judge crosses the line into the realm of arrogance, in part, because history is replete with instances of judicial arrogance. By judicial arrogance, I refer to instances in which the Court overestimates (or assumes) the correctness of its decision. Judicial overconfidence in the nineteenth century is reflected most profoundly in the Court's decision in Dred Scott v. Sanford. ${ }^{122}$ Described by Robert Bork as "the worst constitutional decision of the nineteenth century" 123 and by Alexander Bickel as a "ghastly error," 124 the Dred Scott case, and in particular Justice Taney's majority opinion, exude a level of arrogance and presumptuousness not typically found in controversial constitutional cases. Justice Taney erroneously presumed that the Court's emphatic denial of Dred Scott's citizenship would be sufficient to resolve the brewing controversy of the status of blacks in American public law. ${ }^{125}$ For this reason,

claim was rejected and summary judgment was granted 10 the defendants by the district court in a subseguent opinion. Gratz. v. Bollinger, 135 F. Supp. 2d 790 (L.D. Mich. 2001).

I21. GOLDBERG, stipra nole 52, al 237.

122. 60 U.S. $393(1857)$

123. ROBERT H. BORK, THMPTING; OF: AMIERICA: THE POLITICAL, SEDUCTION OI: THE: I,AW 28 (1990).

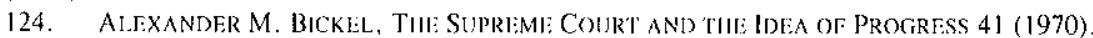

125. Instead, as Profesor Jamin Raskin points out. "Dred Scot's explicitly constioutionalized white supremacy /would be] destroyed by the Civil War and the Ipassage of the Thirtecenth. Fourlecnth, and Fifieenth Amendments," Jamin B. Raskin, The Sipreme Court's Racial Domble Siandard in Redistricting: Unequal Protection in Politics and the Scholawhip that Defends h, 14 J.1. \& PO1., 591, 603 (1998). In the years that followed. Justice Taney was roundly eriticized by both liberals and conservalives for his abuse of the Court's authority. As Prolessor Mark Graber explains:

Tancy's claims abou black citizenship and slavery in the territories have been criticized for three distinct and inconsistent lailings. One line of criticism claims that Dred Scot rests on a mistaken theory of the proper role of judicial instiutions in a democratic society. Robert McCloskey. Alexander Bickel, Lino (iraglia, Cass Sunstein and other proponents of judicial restraint mainain that the Supreme Court should not have made any authoritative attempt, even one based on the constitution, to resolve the constitutional controversy over 
the Court's decision in Dred Scott is near universally condemned as a judicial disaster. ${ }^{126}$

In response to concerns about judicial arrogance, a number of scholars and jurists over the years have counseled in favor of judicial humility. Felix Frankfurter famously advocated the need for judicial humility, ${ }^{127}$ and praised others who exuded it. ${ }^{28}$ Dean Erwin Griswold of the Harvard Law School, in a 1962 tribute to Frankfurter, remarked that Frankfurter emphasized "the integrity of the judicial process, of the essential importance of sound procedures, of judicial self restraint, and of the intellectual humility of the judge." ${ }^{29}$ Justice Breyer has commented that judges should "consider the constitutionality of statutes with a certain modesty,"130 and suggested a "need for judicial caution and humility when certain privacy matters, such as the balance between free speech and privacy, are at issue." 131 Thus, while embracing courage and steadfastness, judges seeking to realize democracy in cases where minority interests are at stake should be careful to avoid pitfalls associated with judicial arrogance.

the status of slavery in the territories. The other two criticisms claim that Dred Scott rests on a mistaken theory of constitutional interpretation. Robert Bork, David Currie, Don Fehrenbacher and other historicists condemn the Taney opinion for relying on personal notions of justice instead of on the specific norms set down by the constitutional framers and previous judicial precedents. Thurgood Marshall, Sotirios Barber, Christopher Eisgruber and other aspirationalists, in contrast, condemn the Taney opinion for not tempering the specific policies set out by the constitutional framers and past judicial precedents with more general notions of constitutional and human right.

Mark Graber, Desperately Ducking Slavery: Dred Scott and Contemporary Constitutional Theory, 14 CONST. COMMENT. 271, 276-77 (1997).

126. Carl B. SWiSher, 5 History of the Supreme Court of the United States: The Taney PERIOD, 1836-64, at 631 (Paul A. Freund ed. 1974) (concluding that Died Scot case "has gone down in history as a major disaster. degrading the Court and the Constitution and precipitating the Civil War"); Michael J. Gerhard, The Lives of John Marshall, 43 WM. \& MARY L. REV. 1399, 1408 (2002) (remarking that Chief Justice Taney's reputation never recovered, though he remained on the Court for almosi another decade and quoting Taney's biographer as conceding that Taney "died in virtual public disgrace"); Cass R. Sunstein, Foreword: Leaving Things Undecided. 110 HaRV. L. REv. 4, 48 (1996) (describing the Dred Scon case as a one of the "most vilified cases in the Court's history"). For more statements condemning the Dred Scot decision, see Graber, supra note 125, at $271-73$.

Contemporary examples of judicial arrogance often entail Court entanglement in politics or the expression of an opinion in areas in which it has little, if any, real expertise. See, e.g.. PGA Tour, Inc. v. Martin, 532 U.S. 661, 692 (2001) (deciding whether walking the course is essential to the game of golf); Bush v. Gore, 531 U.S. 98 (2000) (deciding the outcome of the 2000 presidential election); Shaw v. Reno, 509 U.S. 630, 636, 647 (1993) (objecting to the boundaries of a North Carolina majority-minority voting district for, among other reasons, that the district was "snake like" and that the designation of such a district "bears an uncomfortable resemblance to political apartheid").

127. Felix Frankfurter, Chief Justices I Have Known, 39 VA. L. REv. 883 (1953).

128. Felix Frankfurter, Mr. Justice Roberts. 104 U. PA. L. REV. 311 (1955).

129. Erwin N. Griswold, Felix Frankfurter-Teacher of the Law, 76 HARV. L. REV. 7, 11 (1962).

130. Stephen Breyer, Our Democratic Constiturion, 77 N.Y.U. L. REv. 245, 250 (2002).

131. Id. at 261 . 
III. CONCLIUSION

I have argued essentially three points in this Article. First, the persistence of social hierarchical arrangements within American democracy that create and reinforce social and economic inequality between members of the majority and socially disfavored and minority groups poses a serious challenge to the realization of fundamental democratic ideals of freedom, justice, and equality. Second, in certain instances where the majority will is pitted against minority rights and interests, judges play a crucial role in realizing democracy for subordinated groups through the adjudication of disputes in a manner consistent with the antisubordination principle. Third, free jazz is a useful metaphor in terms of developing a style or approach to adjudication that attempts to realize democracy for subordinated groups. When confronted with a case that demands vindication of the rights and interests of subordinated groups in the face of majority rule, judges, like their jazz counterparts, should place freedom (disciplined by the antisubordination principle) at the center of the adjudicative enterprise, and approach the task of judging with creativity, commitment, and courage. In cases where the rights and interests of members of socially disfavored groups are in jeopardy, judges should not reflexively indulge the status quo or the path of least resistance, but act affirmatively and forthrightly in a manner consistent with the best of the American constitutional, democratic, and free jazz tradition. In this way, judges can help nurture and sustain a culture of democracy that responds meaningfully to the crisis of social and economic inequality and moves us closer, as a nation, to realizing our democratic destiny. 